\title{
Diversity and distribution of Miocene-Pliocene sepiids (Cephalopoda) in the Mediterranean area, with new records from Italy and Turkey
}

\author{
Martin Košt'ák ${ }^{1}$ (D) John W. M. Jagt ${ }^{2} \cdot J^{\prime}$ Jan Schlögl ${ }^{3}$
}

Received: 14 September 2018/ Accepted: 17 November 2018/Published online: 30 November 2018

(C) Akademie der Naturwissenschaften Schweiz (SCNAT) 2018

\begin{abstract}
Two new records of Cenozoic sepiids from the Mediterranean area are described and discussed. While the single, fragmentary specimen from Pliocene (Zanclean) strata in northwestern Italy can only be identified generically as Sepia sp., the Turkish Sepia vandervoorti sp. nov., of late Langhian-earliest Serravallian (Middle Miocene) age, constitutes a new species. The diversity and disparity of Cenozoic sepiids from the Mediterranean area are discussed within palaeobiogeographical and stratigraphical contexts. Current cuttlefish records from the Central Paratethys, the Atlantic coast and the North Sea Basin provide indications of migration patterns of the genus Sepia during the Miocene. A synthesis of published data, complemented by the new records presented here, allows us to reconstruct sepiid distribution in time and space. The highest diversity and morphological disparity are seen during the Middle Miocene; this is followed by a rapid decrease during the Late Miocene and a renewed radiation during the Pliocene.
\end{abstract}

Keywords Sepia $\cdot$ Palaeobiogeography $\cdot$ Southern Europe $\cdot$ Near east $\cdot$ Cenozoic $\cdot$ New species

\section{Introduction}

In general, cuttlebones of extinct sepiids related to the genus Sepia Linnaeus 1758 are considered to be rare in the fossil record. In this respect, each new record of fossil representatives constitutes a notable contribution to the evolutionary history and palaeobiogeography of sepiids. During recent years, new records have been described from

Editorial Handling: D. Fuchs.

Martin Košt'ák

martin.kostak@natur.cuni.cz

John W. M. Jagt

john.jagt@maastricht.nl

Jan Schlögl

jan.schlogl@uniba.sk

1 Institute of Geology and Palaeontology, Faculty of Science, Charles University, Prague, Albertov 6, 12843 Prague 2, Czech Republic

2 Natuurhistorisch Museum Maastricht, De Bosquetplein 6-7, 6211 KJ Maastricht, The Netherlands

3 Department of Geology and Paleontology, Faculty of Natural Sciences, Comenius University in Bratislava, Mlynska dolina, Ilkovičova 6, 84215 Bratislava, Slovakia the Central Paratethys, Australia and the North Sea Basin (Košt'ák et al. 2016, 2017; Košt'ák and Jagt 2018), as well as from the Lower Pleistocene of central Italy (Pasini et al. 2014). Extant cuttlefish evolved from a stem lineage of Recent Sepia, which derived from Oligocene archaeosepiids (Košt'ák et al. 2017). The majority of Oligocene records (archaeosepiids) come from Hungary and Italy (Lőrenthey 1899; Szörényi 1933; Wagner 1938; Fornasiero and Vicariotto 1995), where these forms made their first appearance approximately following the extinction of another group of extinct sepiids, the belosaepiids. Consequently, the origin of extant cuttlefish probably is linked to the Paratethys and Mediterranean areas. The highest diversity, as well as the greatest morphological disparity amongst fossil sepiids, is seen during the Middle Miocene (Košt'ák et al. 2016). It is notable that the highest sepiid diversity worldwide is seen in the Recent (Reid et al. 2005); the same holds true for a very high morphological disparity of cuttlebones (Neige 2003a, b, 2006; Neige and von Boletzky 1997).

Historically, ancestral sepiids from the Mediterranean area were studied by several scholars during the nineteenth century (e.g. Gastaldi 1866; Bellardi 1872; Ponzi 1876; Tiberi 1880; Issel 1889; Foresti 1890; Parona 1892). Later work includes that by Sacco (1904), Lipparini (1934), 
Álvarez Ramis and Meléndez (1966), Hewitt and Pedley (1978), Abad et al. (1981), Cavallo and Repetto (1992) and others. The most recent papers are those by Gaudant et al. (2007), Okan and Hoşgör (2009) and Pasini et al. (2014). On the basis of published data and new records from Italy and Turkey, we here summarise the stratigraphical distribution and palaeobiogeographical aspects of extinct sepiids from the Mediterranean area.

\section{Geological, geographical and stratigraphical setting}

Turkey: marine strata in the Mut Basin have been subdivided into five units, namely the Mut, Köselerli, Dağpazarı, Tirtar and Ballı formations (Atabey et al. 2000). The Mut and Köselerli formations are the oldest units in this sequence and frequently demonstrate lateral interfingering; they have been dated as late Burdigalian and Langhian (Mut Formation) to earliest Serravallian (Köselerli Formation). The Mut Formation comprises mainly limestones, while the Köselerli Formation consists of clayey limestone and marl. The new sepiid was collected from grey marls of the latter formation and can be dated as late Langhianearliest Serravallian. This age assignment of the marls is confirmed by the abundant material of the pteropod Vaginella austriaca Kittl, 1886 and the gastropod Sulcogladius collegnoi (Bellardi and Michelotti, 1841) var. pluridenticulata Sacco, 1893, which was originally described from the Turin hills in Italy as characteristic of the "Helvetian"; this currently corresponds to the Langhian/Serravallian.

Italy: Montaldo Roero (Trinità, province of Cuneo, Italy; co-ordinates: $44^{\circ} 45^{\prime} 44^{\prime \prime} \mathrm{N}-7^{\circ} 56^{\prime} 16^{\prime \prime} \mathrm{E}$ ) from Lower Pliocene (Zanclean) strata.

\section{Materials and methods}

The Turkish specimen (part and counterpart, in matrix) was discovered and collected (May 1989) near the village of Palantepe (near Mut, Mersin Province, southern Turkey) by Mr. Jaap van der Voort (Ostercappeln, Germany) from grey marls of the Köselerli Formation, which is dated as late Langhian-earliest Serravallian. The fragmentary specimen from northwestern Italy (Montaldo Roero, province of Cuneo) originates from Lower Pliocene (Zanclean) strata and is completely free of matrix.

Specimens were measured and studied using the computer graphic programs CorelDRAW X5 and CorelPhotoPaint X5. Photographs were taken with a digital camera (Canon EOS D600D). The terminology used herein is based mainly on the preserved dorsal parts of the cuttlebone (i.e. more specifically, the shape of the dorsal shield, the presence of median and lateral keels, the character of the apical part ["rostrum"], the shape of septal suture lines and the arrangement of granules on the dorsal shield) follows previous systematic treatments by Bizikov (2008), Košt'ák et al. (2016) and Košt'ák and Jagt (2018). Schematic general shapes of cuttlebones are shown in Fig. 1.

\section{Systematic palaeontology}

Subclass Coleoidea Bather, 1888

Order Sepiida Gray, 1849

Family Sepiidae Keferstein, 1866

Genus Sepia Linnaeus, 1758

Sepia vandervoorti sp. nov.

Figures 2, 3a-g

Diagnosis Smaller-sized sepiid with rhomboid cuttlebone possessing fine granulation, relatively wider outer cone, oval-rounded inner cone with fork and well-developed prong. Median and lateral fields without ornamentation.

Types The holotype, and sole specimen known to date, is RGM.1351051.a (part) and RGM.1351051.b (counterpart), in the collections of Cenozoic Mollusca at Naturalis Biodiversity Center (Leiden, the Netherlands; formerly Rijksmuseum van Geologie en Mineralogie).

Derivatio nominis In honour of Mr. Jaap van der Voort (Ostercappeln-Venne, Germany), who found the specimen in May 1989.

Locus typicus Outcrop on the eastern side of the road (D715) from Karaman to Mersin, between the northern margin of the village of Palantepe with the mosque and the village itself (co-ordinates: $36^{\circ} 36^{\prime} 53.50^{\prime \prime} \mathrm{N}-33^{\circ} 26^{\prime} 28.60^{\prime \prime} \mathrm{E}$ ). This locality is within the Mut Basin, which comprises strata of Miocene age (see below).

Stratum typicum Köselerli Formation (late Langhian-earliest Serravallian).

Description: Complete specimen with an oval to rather rhomboid cuttlebone (Figs. 2, 3a, b) with partially preserved shell (Fig. 3a); a smaller-sized member of Sepia $(L=51 \mathrm{~mm})$, the widest part $(\sim 18 \mathrm{~mm})$ being situated approximately in the middle part. Dorsal surface with slightly developed median keel, widening anteriorly under a low angle $\left(7^{\circ}\right)$. Where preserved, the cuttlebone surface (shell remnants preserved in the posterior part only) shows regularly arranged fine granules (Fig. 3f). No prominent granules are visible. 
Fig. 1 General cuttlebone shape (dorsal view; not to scale); a prolonged oval; $\mathbf{b}$ oval; c ovalrhomboid; d rhomboid; e ovalrhomboid to elliptical with posterior wings expanded (from Košt'ák et al. 2016)

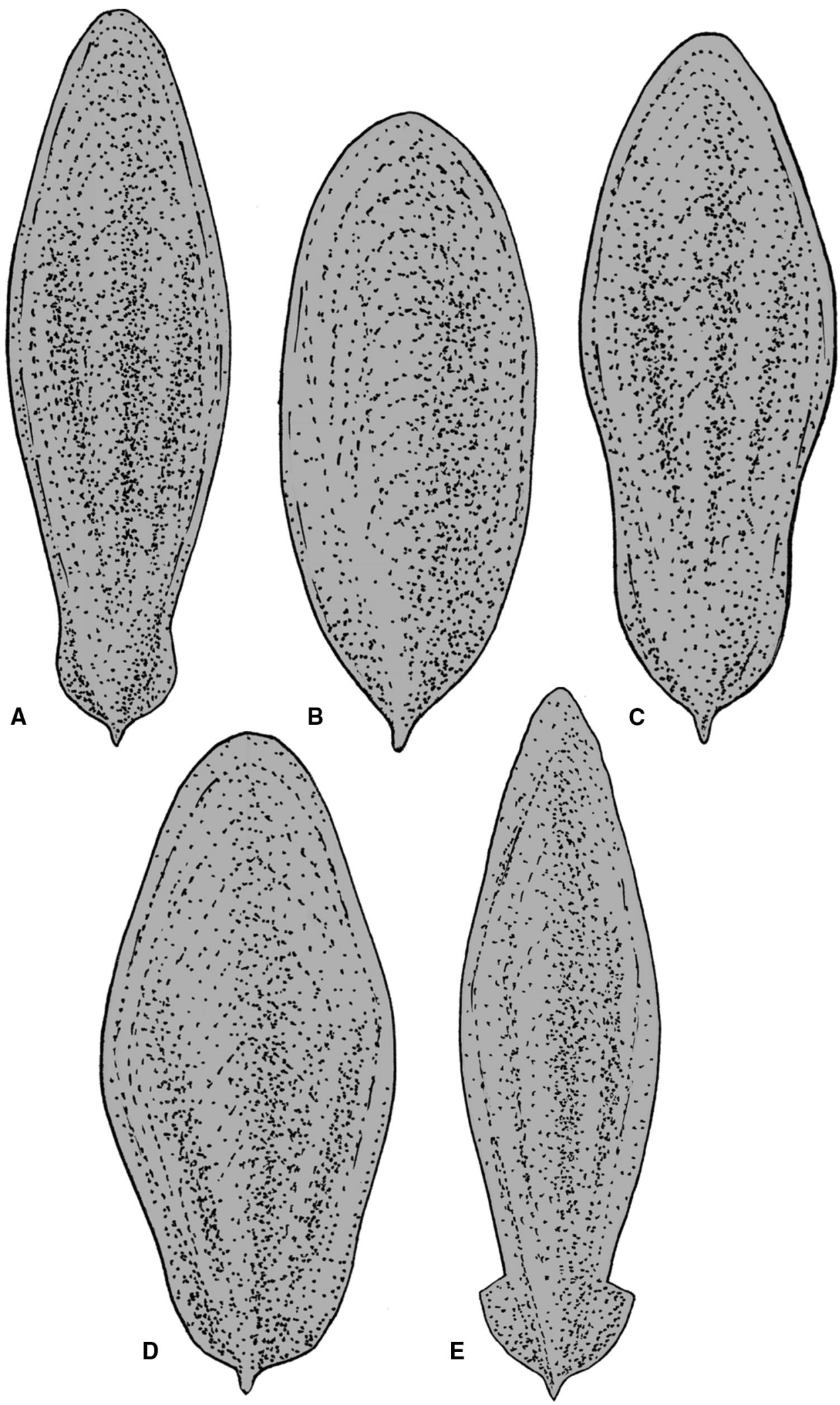

Lateral fields (diverging at an angle less than $38^{\circ}$ ) are well developed, lacking ornamentation or 'false' lateral keels. Lateral fields only slightly separate the median field from the flattened lateral sides. Anterior margins slightly splayed. Septal suture lines parallel and rhomboidal (Fig. 3e) in the anterior part, semi-circular-oval in early 


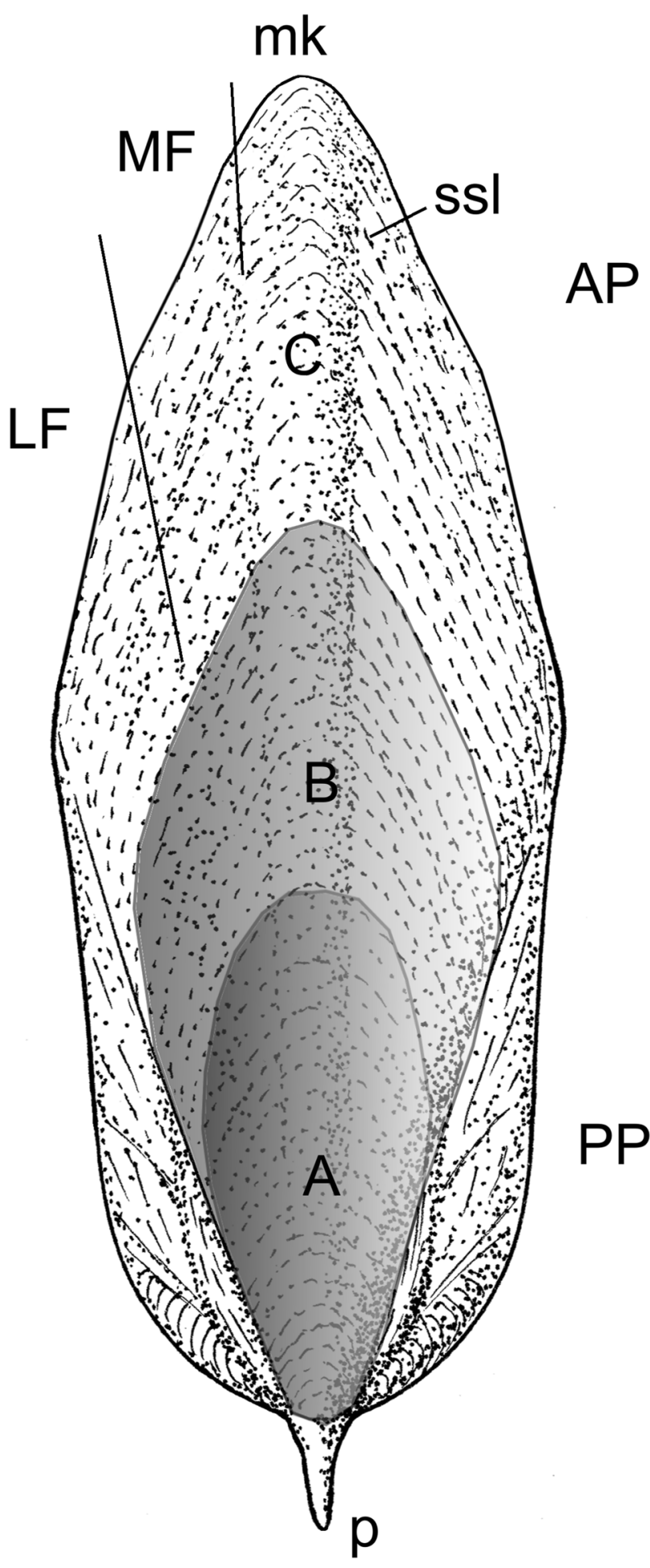

Fig. 2 Reconstruction of the cuttlebone of $S$. vandervoorti sp. nov., as based on morphological features preserved on part and counterpart of the holotype (RGM.1351051.a, RGM.1351051.b); $p$ prong (rostrumlike structure), $A P$ anterior part, $P P$ posterior part (including wings, outer and inner cones), $L F$ lateral field, $M F$ median field, $m k$ median keel, ssl septal suture lines. a Early ontogenetic stage with oval shape of dorsal shield. b Juvenile to adolescent ontogenetic stage with partially rhomboid shape of dorsal shield. c Adult ontogenetic stage with rhomboid shape of dorsal shield ontogenetic stages showing significant changes in shape during ontogeny.

Originally chitinous rims are absent. Calcareous rims are only slightly indicated. Well-calcified remains of inner and outer cones are quite well preserved (Fig. 3d). Outer cone relatively wide, possessing fine striation. Pillar structure imprints (intracameral walls) are seen only in one place of the cuttlebone (Fig. 3e-g), revealing the typical arrangement of the genus Sepia. Morphological features of the ventral surface unknown.

Prong well developed (Fig. 3c, d), subcircular to oval in cross section, situated centrally. The length is $3.2 \mathrm{~mm}$ and width $1.3 \mathrm{~mm}$. The entire surface is smooth.

Discussion and remarks The new species differs from the majority of Miocene taxa that have been recorded from the Mediterranean and Paratethys areas by its oval-rhomboid to rather rhomboid (i.e. slightly laterally compressed) shape of the dorsal shield. Such a morphology is rare amongst sepiids. Overall, there are only few records from the Miocene of Sardinia (S. caralitana Parona, 1892) and a specifically indeterminate specimen, Sepia sp., from Turkey (Okan and Hoşgör 2009) that show this morphology. These taxa are similar in that they also have a rhomboid cuttlebone, but this is significantly shorter and wider than the one in S. vandervoorti sp. nov. In addition, the Middle Miocene S. caralitana, from Fangario (Cagliari, Sardinia), shows a much wider outer cone and even lateral fields are well separated from the median field by the lateral keel. In retaining rhomboid growth lines from the earliest stages, the ontogeny of $S$. caralitana documents isometric growth of the dorsal shield. The Early Miocene Sepia sp. from the Yukaribedvan section (Diyarbakir, Turkey) is incompletely preserved. However, this represents another taxon with a different shape of growth lines. A Pliocene record, with more or less similar characteristics (mostly shape) was described from northern Italy as Sepia sp. by Cavallo and Repetto (1992, p. 235, fig. 710). This individual is damaged, slightly deformed and does not preserve important morphological features.

The overall shape of the cuttlebone reflects two stages of ontogenetic development. The oval shape is well recognised up to approximately fifty per cent of the overall length of the cuttlebone (Fig. 2). From this point onwards, the cuttlebone becomes increasingly more rhomboid and later ontogenetic stages reveal a strictly rhomboid character (Figs. 2, 3e).

\section{Sepia sp.}

Figures $3 \mathrm{~h}-\mathrm{k}, 4$

Material A single fragmentary specimen, RGM.1351052, collected by Mr. Jaap van der Voort. 

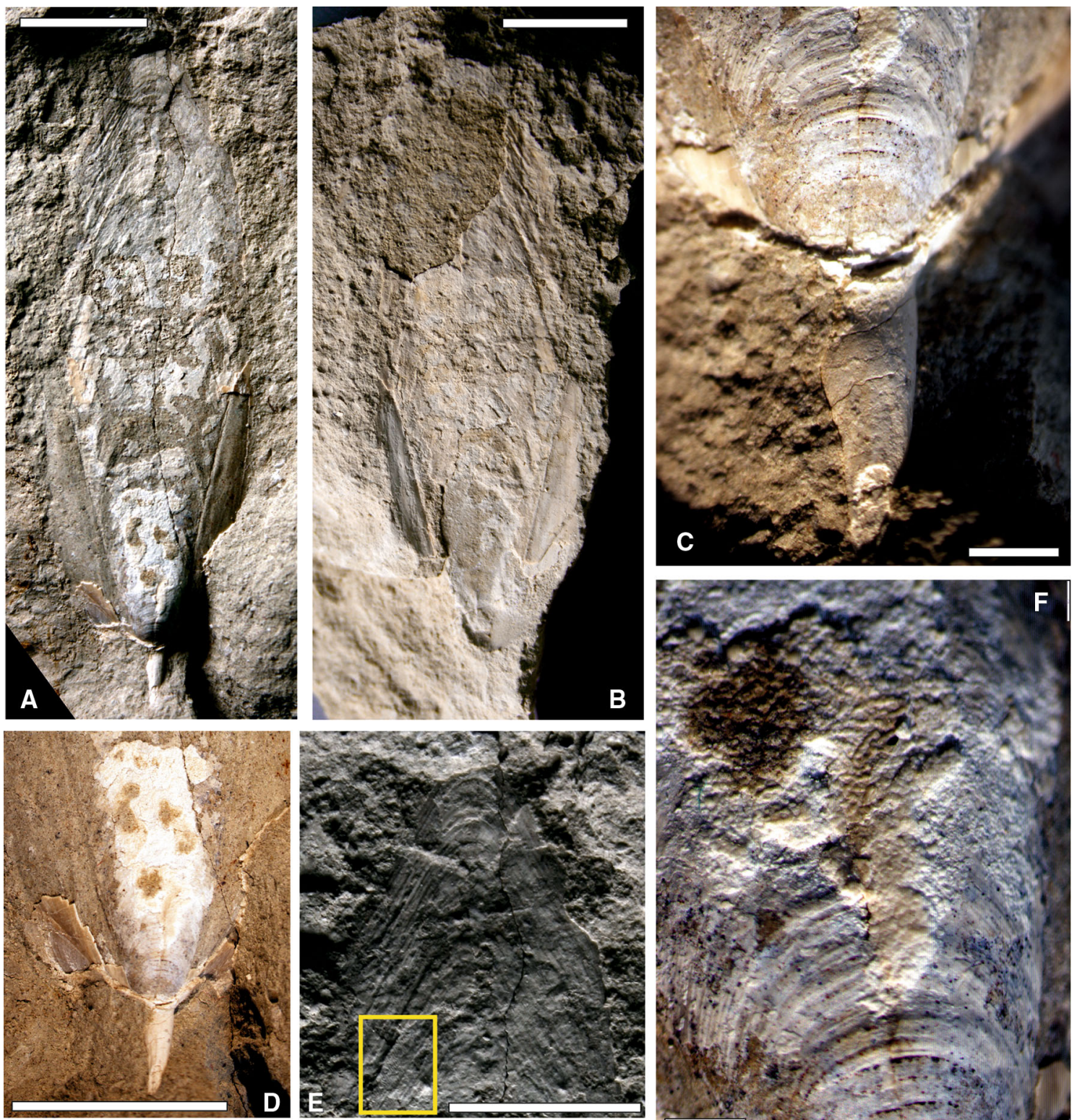

B

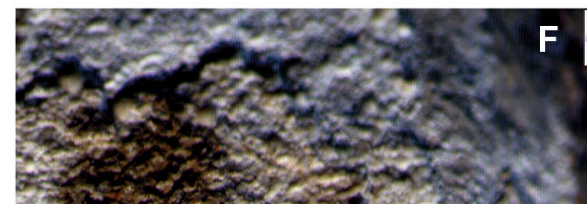

-
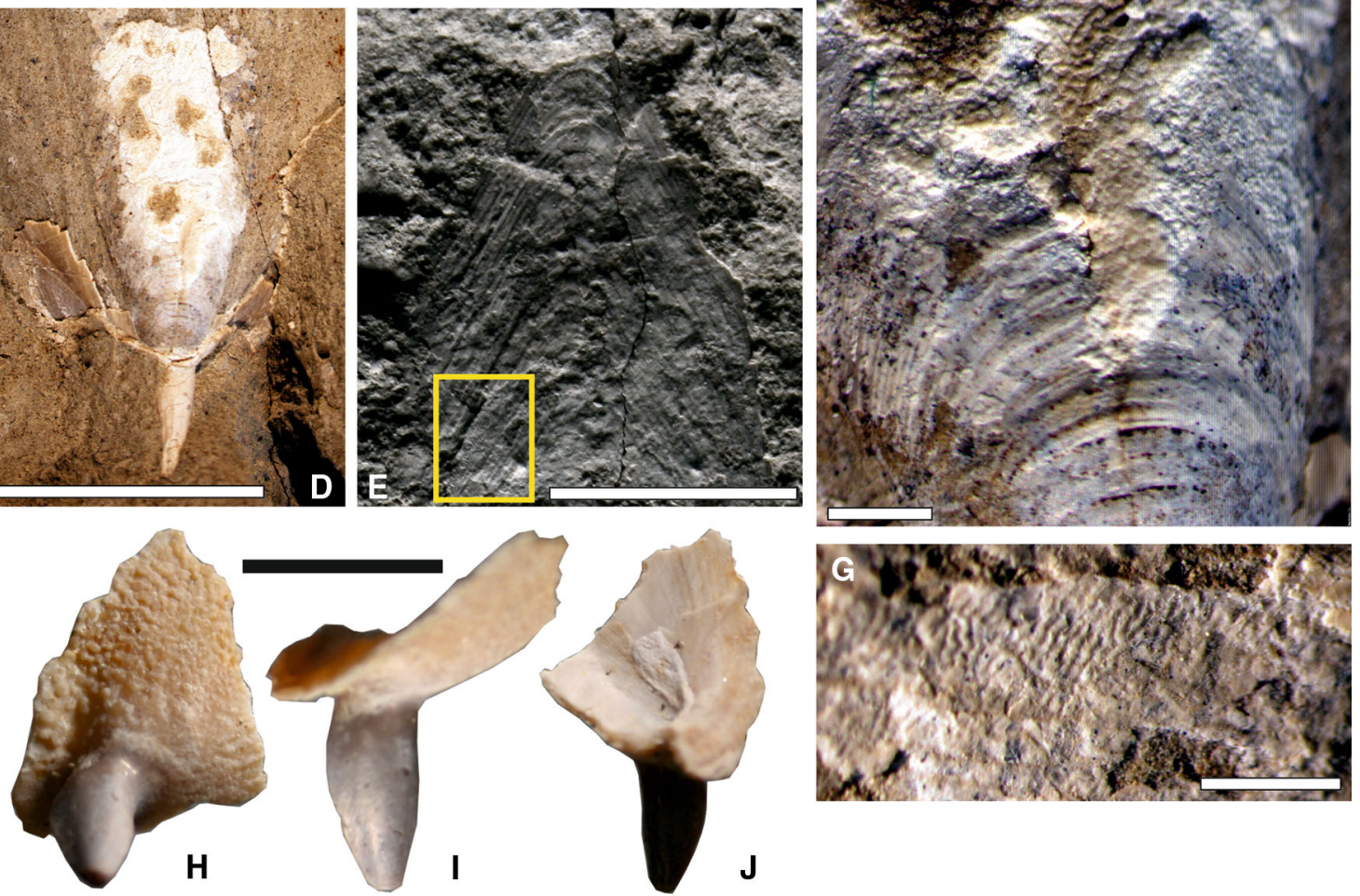

Fig. 3 Sepia vandervoorti sp. nov., Middle Miocene (upper Langhian-lowermost Serravallian). a RGM.1351051.a (part), with partially preserved dorsal shield and its imprints, documenting a narrow median keel. b RGM.1351051.b (counterpart). Scale bars equal $10 \mathrm{~mm}$. c Detail of the prong and early ontogenetic chambers of the phragmocone. Scale bar equals $1 \mathrm{~mm}$. d Apical part of the cuttlebone with shell remnants of the outer and inner cones. Scale bar equals $10 \mathrm{~mm}$. e Detail of typically rhomboid characters of the anterior part of the cuttlebone. The square indicates where imprints of pillar structure are preserved. Scale bar equals $10 \mathrm{~mm}$. f Remains of the dorsal shield with fine granulation. Scale bar equals $1 \mathrm{~mm}$. $\mathbf{g}$ Detail of imprints of pillar structure (intracameral walls). $\mathbf{h}-\mathbf{k}$ Sepia sp., Lower Pliocene (Zanclean), northwestern Italy. i Connection of finely granulated shield with smooth prong. $\mathbf{j}$ Lateral view of the knifelike prong. $\mathbf{k}$ Ventrolateral view of phragmocone. Scale bar equals $10 \mathrm{~mm}$ 


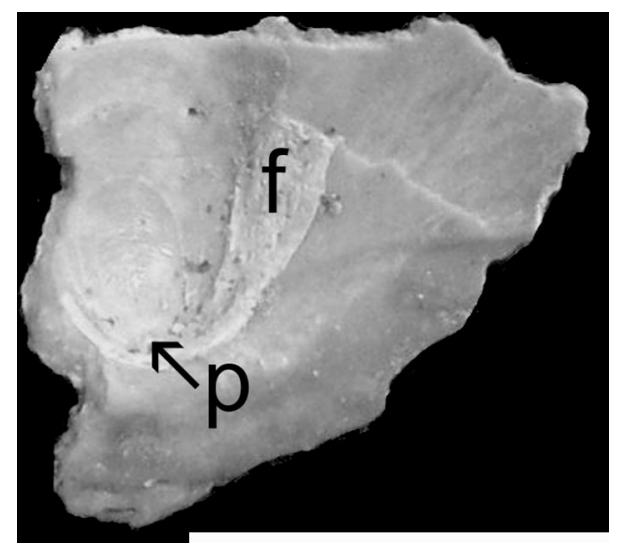

Fig. 4 The earliest/embryonic chambers with protoconch (p), outer and inner cones and remains of the fork (f) of RGM.1351052. No pillar structures are seen in the first chambers. Scale bar equals $10 \mathrm{~mm}$

Description Fragment, $12.2 \mathrm{~mm}$ in greatest preserved length, of the apical portion of a cuttlebone, consisting of the granulated remains of the dorsal shield and a completely preserved prong. The granulation is fine, regularly distributed over the shell surface but effacing where the shell connects to the prong. Inner part of the shell reveals the protoconch, three chambers, the inner cone and remains of the fork (Fig. 4). The inner cone is oval-rounded with well-developed fork limbs. The fork is narrow at the protoconch area and diverges significantly anteriorly (Fig. 4); however, only the posteriormost part is preserved. No imprints of pillar structure (intracameral walls) are seen in the chambers. Chambers are typically oval in ventro-dorsal view in the earliest ontogenetic stages, with width increasing during growth.

The prong measures $5.5 \mathrm{~mm}$ in length and has a maximum width of $2.8 \mathrm{~mm}$; it is medially robust, asymmetrically lanceolate (i.e. knife-like) in lateral aspect and conical $\left(20^{\circ}\right)$ in dorso-ventral view. The prong is straight on the dorsal side, the ventral side revealing a clear curvature formed by a knife-like edge; it possesses a welldeveloped, sharp carinal margin in the ventral part. The visible extension in the lateral view is situated at approximately one-third of the posterior part of the prong. The prong is situated centrally without inclination and is ovalrounded in cross section. The surface of the prong is not striated. The ventrolateral planes/depressions are well developed towards the apex.

Discussion and remarks Apical portions of cuttlebone represent the most commonly recorded fragments of ancient sepiid shells (and of their ancestors, i.e. belosaepiids and other groups). This part is heavily calcified in both extinct and extant Sepiidae, and thus has a high potential of becoming fossilised. However, the systematic value of this portion of the cuttlebone is rather limited. Only few taxa that retain typical morphological features of the apical portion, such as Sepia sanctacrucensis Bałuk, 1977 can be identified at the species level (Košt'ák et al. 2016). The variability and systematics of the rostrum-like structure, i.e. the prong, in both fossil and extant sepiids have never been studied in detail, which is why the apicalmost part of the cuttlebone cannot be used for specific placement of the present specimen. The fine granulation of the shield is a quite common morphological feature amongst representatives of the genus Sepia. The inner cone feature and even the presence of the fork/fork limbs and its character may determine this fragment within the subgenus $S$. (Sepia), as the majority of other subgenera have a different inner cone/fork character.

\section{Distribution and diversity in time and space}

\section{Early Miocene}

Early Miocene sepiids from the Mediterranean area are best known from northern Italy, with records of Sepia gastaldii Bellardi, 1872, S. cf. rugulosa var. miocebana Sacco, 1904, S. michelottii Gastaldi, 1866, and from Malta, with ?Sepia sp. (sensu Hewitt \& Pedley 1978). In addition, there is a single record from Turkey, Sepia sp. (sensu Okan \& Hoşgör 2009). The Lower Miocene of the Mediterranean area was characterised by an open connection with the Atlantic Ocean and the North Sea in the west and northwest, as well as an easterly corridor to the Tethyan Ocean via the Mesopotamian Basin (Fig. 5). These relatively wide straits may have functioned as migration corridors for cuttlefish. Indeed, cuttlefish did migrate eastwards via this easterly pathway to reach India at that time (i.e. Early Miocene, Burdigalian; see Mohan and Chatterji 1956). According to Košt'ák et al. (2017), this migratory direction had previously been used by archaeosepiids which were probably the direct ancestors of the stem lineage of Sepia. The northerly (towards the North Sea) and westerly (towards the Atlantic coasts) pathways may also have been used during the late Early Miocene (and before, during the Eocene by belosaepiids). However, in view of the fact that we have no Early Miocene sepiid records from these areas, this is merely speculative, although there is some support from the Middle Miocene (late Langhian) Sepia fabianschwankei Košt'ák and Jagt, 2018 from northern Germany (North Sea Basin). Migration in a northerly direction appears unlikely during the Middle Miocene, because the connective corridor between the North Sea Basin and the Mediterranean had already been closed (Fig. 5). Consequently, this migration may have occurred already during the Early Miocene (Košt'ák and Jagt 2018). It is of note that the eastern Paratethys is devoid of any sepiid record. This has not been explained to date; we here suggest that 

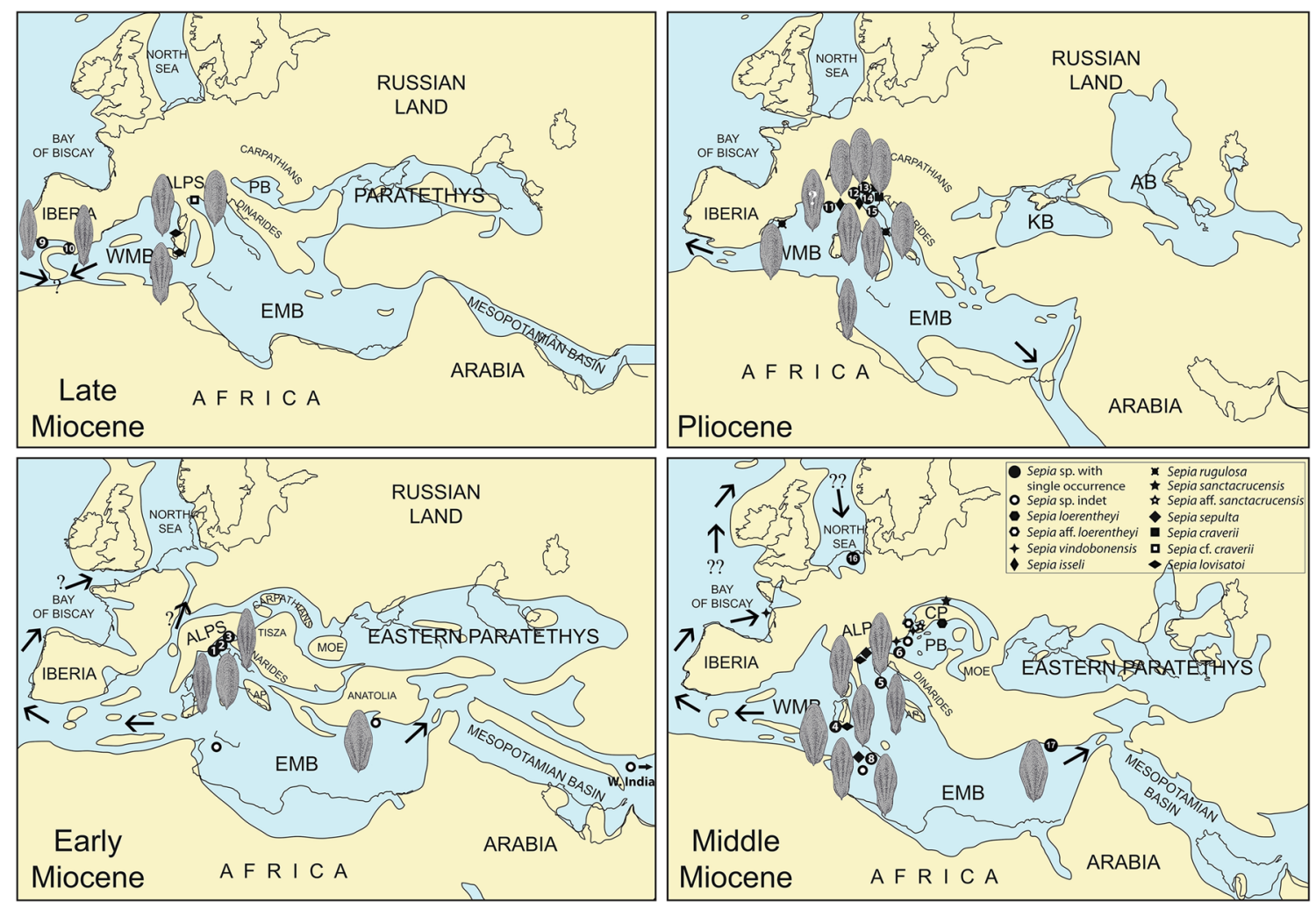

Fig. 5 Palaeobiogeography (modified from Košt'ák et al. 2016) with migration routes (arrows). Palaeogeographical distribution of Miocene-Pliocene cuttlefishes (maps after Popov et al. 2004; slightly modified). $A B$ Akchagilian Basin, $A P$ Apulia, $C P$ Carpathians, $E M B$ Eastern Mediterranean Basin, $K B$ Kujalnician Basin, $M C$ Massif Central, $M O E$ Moesian Land, $P B$ Pannonian Basin, $W M B$ Western Mediterranean Basin. Numbers within the circles refer to the following taxa: 1, Sepia gastaldii Bellardi, 1872; 2, Sepia cf. rugulosa var. miocebana Sacco, 1904; 3, Sepia michelottii Gastaldi, 1866; 4, Sepia caralitana Parona, 1892; 5, Sepia saccoi Lipparini,

salinity may have played a key role, principally from the late Middle Miocene onwards. However, the absence of cuttlefish during the Early Miocene remains a mystery; sampling bias cannot be the sole reason for this pattern.

\section{Middle Miocene}

The Middle Miocene of the Mediterranean area is characterised by a high cuttlefish diversity, the greatest morphological disparity (sensu Neige 2003a) in sepiid history (Fig. 5) and the widest geographical distribution in the fossil record known to date. About nine species have been recorded from central and northern parts of the Mediterranean, namely Sepia lovisatoi Parona, 1892, S. sepulta Michelotti in Bellardi, 1872; Sepia sp. (sensu Hewitt and Pedley 1978), S. caralitana Parona, 1892, ?S. lovisatoi Parona, 1892, S. cf. harmati Szörényi, 1933 (sensu Hewitt and Pedley 1978), ?S. verrucosa Bellardi, 1872 (sensu Sacco 1904) and Sepia saccoi Lipparini, 1934. Sepia

1934; 6, Sepia mikuzi Košt’ák, Schlögl, Hudáčková, Kroh, Halásova, Gašparič, Hyžný and Wanzenböck, 2016 and Sepia aff. mikuzi; 7, Sepia juliebarborae Košt'ák, Schlögl, Hudáčková, Kroh, Halásova, Gašparič, Hyžný and Wanzenböck, 2016; 8, Sepia cf. harmati Szörényi, 1933; 9, Sepia melendezi Mayoral \& Muñiz, 1994; 10, Sepia (Parasepia) orbignyana bética Álvarez Ramis and Meléndez, 1966; 11. Sepia granosa Bellardi, 1872; 12, Sepia verrucosa Bellardi, 1872; 13, Sepia stricta Bellardi, 1872; 14, Sepia complanata Bellardi, 1872; 15, Sepia bertii Foresti, 1890; 16, Sepia fabianschwankei Košt'ák and Jagt, 2018; 17, Sepia vandervoorti sp. nov.

vandervoorti sp. nov. significantly extends the palaeobiogeographical record of the Middle Miocene cuttlefish to the eastern parts of the Mediterranean. A diverse sepiid fauna has recently also been recorded from the Central Paratethys and those species show some affinities with the Mediterranean taxa (Košt'ák et al. 2016, discussion therein). The connection between the Central Paratethys and the Mediterranean area is obvious. Species from the Central Paratethys reveal signs of allopatric speciation. At the time, the westerly migration corridor to the Atlantic coast remained open and the record of $S$. vindobonensis von Schloenbach, 1869 from Tortonian strata at Saubriges (Biscay Basin, France; see Roger 1947) provides evidence of this. Therefore, we suggest the existence of this Miocene species in the Mediterranean as well in the Atlantic and the Central Paratethys as shown in Fig. 6. The easterly migration corridor was open as well; a new record of Sepia sp. from Australia (Košt'ák et al. 2017) may document a connection via the shelves of the Tethyan Ocean. 

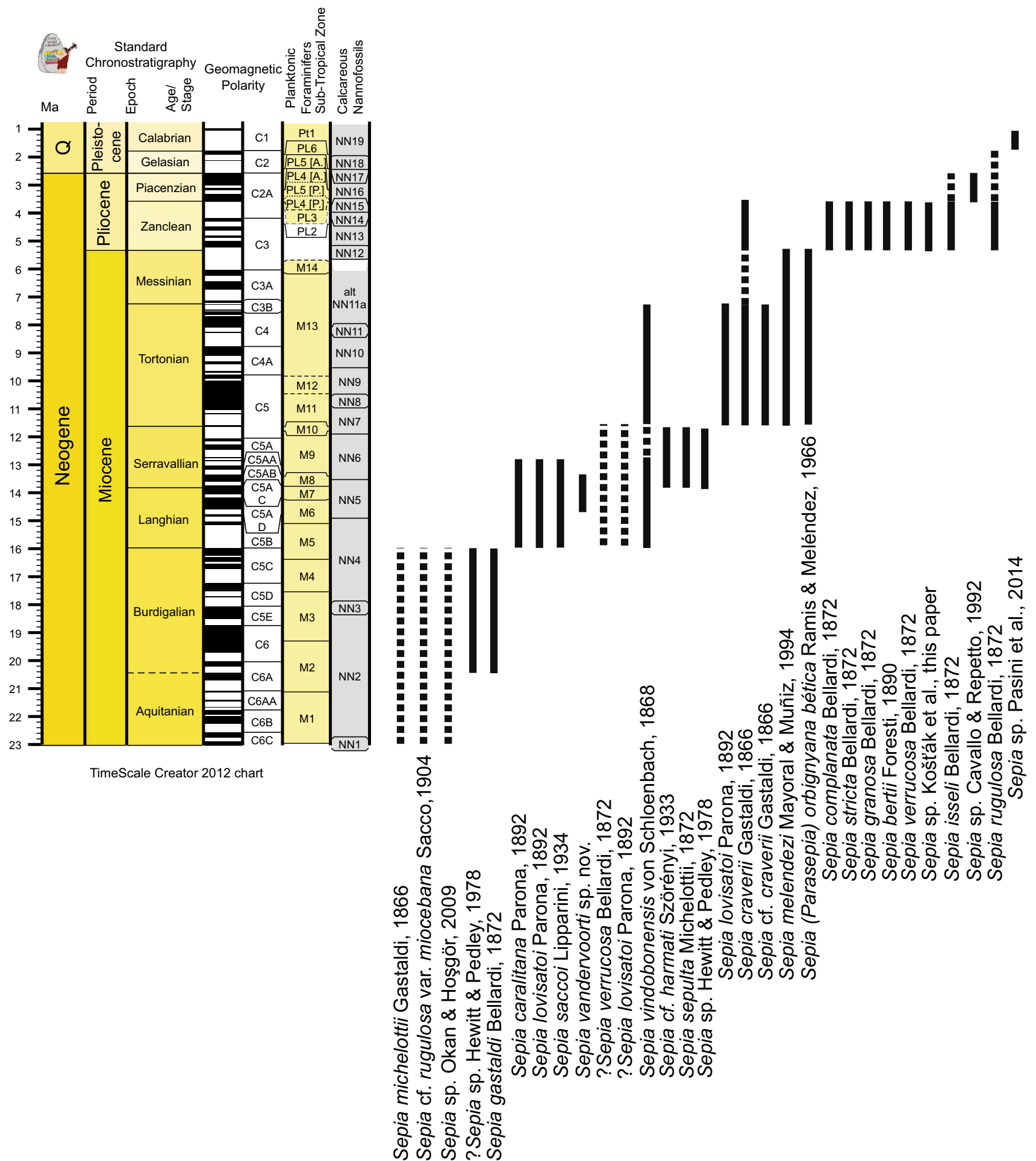

Fig. 6 Stratigraphical distribution of Mediterranean sepiid taxa in the Miocene-Pliocene interval. Sepia vindobonensis and S. melendezi are also included, as the first one is known from Central Paratethys and

Atlantic coast with only possible migration via the Mediterranean and the second one is situated on the northern coast of the Strait of Gibraltar

\section{Late Miocene-Pliocene}

The Late Miocene is characterised by a significant decrease in sepiid diversity; only three species are known from this

time interval. These are the Tortonian Sepia craverii Gastaldi, 1866 and S. lovisatoi and the late Tortonian/ Messinian S. (Parasepia) orbignyana bética Álvarez Ramis and Meléndez 1966. This may have been connected 
to the closure of the eastern corridor, the isolation of the Central Paratethys and even by closure of the Strait of Gibraltar which ultimately resulted in the Messinian Salinity Crisis (MSC) during the late Messinian (Krijgsman et al. 1996). Geographically, these rare records originate from Sardinia and southern Spain. There is, however, another sepiid record from southern Spain, namely Sepia melendezi Mayoral and Muñiz, 1994, from the upper Tortonian/Messinian of Lepe, Huelva; palaeobiogeographically speaking, this belongs to the Atlantic coast, albeit very close to or at the boundary with the Mediterranean s. str.. Only a single species, $S$. craverii, survived the MSC into the Early Pliocene (Fig. 6). As far as we know, there are no records of Late Miocene sepiids from the eastern parts of the Mediterranean area.

Subsequent to the MSC, sepiids experienced a new radiation in the Mediterranean area, their diversity reaching comparably high values to Middle Miocene occurrences. Nine species are known, predominantly from the northern Mediterranean basins of Italy (S. rugulosa Bellardi, 1872, S. verrucosa, S. isseli Bellardi, 1872, S. bertii Foresti, 1890, S. craverii Gastaldi, 1866, S. granosa Bellardi, 1872, S. stricta Bellardi, 1872, S. complanata Bellardi, 1872 and Sepia sp. (sensu Cavallo and Repetto 1992) and a single record from the Western Mediterranean Basin (Barcelona area, Catalonia; see Abad et al. 1981). Specifically, the very high diversity in the northern Mediterranean may be indicative of a radiation centre; to date, there are no records from the central and eastern Mediterranean. Palaeobiogeographically, the connection with the Atlantic coast and the eastern strait to the Red Sea were both open at the time. A synthesis of the stratigraphical distribution is shown in Fig. 6.

\section{Post-Pliocene}

In the literature, there are sporadic records of Pleistocene to Holocene material, e.g. Sepia sp. from the Lower Pleistocene of the Tyrrhenian Basin (Volterra, Pisa area, Italy; see Pasini et al. 2014), Sepia sp. from the uppermost Pleistocene/ Holocene of the Malaga area (Spain; see Jordá et al. 2010) and others. These records all refer to rather fragmentarily preserved material that has not been assessed systematically. For this reason, any documentation of Pleistocene/Holocene sepiid diversity is virtually impossible. In all, extant faunas comprise three species of the genus in the Mediterranean Sea and along the coasts of the Atlantic Ocean (Reid et al. 2005).

\section{Conclusions}

New sepiid records from Middle Miocene and Pliocene strata in the Mediterranean clearly document a high cuttlefish diversity in the area, which is, therefore, considered to be a radiation centre of ancient Sepia. The new record of Sepia vandervoorti sp. nov., from the upper Langhianlowermost Serravallian (Middle Miocene) of Turkey extends the palaeobiogeographical distribution in the Middle Miocene to the Eastern Mediterranean area.

We have summarised all stratigraphical data of known sepiid taxa for the Mediterranean and based on this we have discussed diversity changes in the Miocene-Pliocene interval. The highest diversity has been observed in the Middle Miocene and Lower Pliocene, while the lowest is probably linked to the Upper Miocene crisis. Surprisingly, at least one Mediterranean species ( $S$. craverii) survived into the Early Pliocene in this area.

The palaeobiogeographical distribution of sepiids along the European shelves reveals possible migration patterns, documenting connections to the North Sea and Atlantic coast in the west and to the Tethys in the east.

Acknowledgements Mr. Jaap van der Voort (Ostercappeln-Venne, Germany) is gratefully acknowledged for providing the new fossil sepiid material. This research is supported by projects PROGRES Q45, Center for Geosphere Dynamics (UNCE/SCI/006), APVV-170555 and APVV-14-0118. We sincerely thank the journal reviewers, Dirk Fuchs and Anonymous, for pertinent comments on an earlier version of the typescript.

\section{References}

Abad, A., Fischer, J.-C., \& Vía, L. (1981). Première découverte d'un Sépioïde (Cephalopoda dibranchiata) dans le Pliocène ibérique. Bulletin du Muséum national d́Histoire naturelle Paris, 3(4), 287-299.

Álvarez Ramis, C., \& Mélendez, B. (1966). Hallazgo de una sepia fossil en el Mioceno de Andalucía. Boletín de la Real Sociedad Española de Historia Natural (Geología), 64, 199-202.

Atabey, E., Atabey, N., Hakyemez, A., Islamoğlu, Y., Sözeri, Ş., Özçelik, N., et al. (2000). Mut ve Karaman arasındaki Miyosen havzalarının litostratigrafisi (Central Taurids)ve sedimentolojisi (Orta Toroslar, G. Türkiye) [Lithostratigraphy and sedimentology of the Miocene Basin between Mut and Karaman, (Central Taurids)]. Bulletin of Mineral Research and Exploration, 122, 53-72.

Bałuk, W. (1977). A new species of the cuttlefish from the Korytnica Clays (Middle Miocene; Holy Cross Mountains, Poland). Acta Geologica Polonica, 27, 169-175.

Bather, F. A. (1888). Shell-growth in Cephalopoda (Siphonopoda). Journal of Natural History, 1, 298-309.

Bellardi, L. (1872). I mollusci dei terreni tertiari del Piemonte e della Ligure. Parte I: Cephalopoda, Pteropoda, Heteropoda, Gastropoda (Muricidae et Tritonidae). Torino, 264, p.

Bellardi, L., \& Michelotti, E. (1841). Saggio orittografico sulla classa dei gasteropodi fossili dei terreni terziarii del Piemonte. Memorie della Reale Accademia della Scienze di Torino, 2(3), 93-174. (1-82).

Bizikov, V. A. (2008). Evolution of the shell in Cephalopoda (p. 447). Moscow: VNIRO Publishing.

Cavallo, O., \& Repetto, G. (1992). Conchiglie fossili del Roero, Atlante iconografico. Associazione Naturalistica Piemontese Amici del Museo "F. Eusebio". 
Foresti, L. (1890). Sepia Bertii Foresti. Bollettino della Società Geologica Italiana, 9, 1-5.

Fornasiero, M., \& Vicariotto, G. (1995). Fossil cuttlebones in the Vicentinian Priabonian (Late Eocene, Veneto Region, NE Italy). Memorie di Scienze Geologiche, 47, 173-178.

Gastaldi, B. (1866). Intorno ad alcuni fossili del Piemonte e della Toscana breve nota. Memorie delta Reale Accademia delle Scienze di Torino, 2(24), 193-236.

Gaudant, J., Cavallo, O., Courme-Rault, M. D., Fornaciari, E., Lauriat-Rage, A., de Lapparent, F., et al. (2007). Paléontologie des marnes tortoniennes affleurant dans le lit du Tanaro, près d'Alba (Piémont, Italie). Rivista Piemontese di Storia Naturale, 28, 3-51.

Gray, J. E. (1849). Catalogue of the Mollusca in the collection of the British Museum, Part 1. Cephalopoda Antepedia (p. 164). London: Spottiswoodes and Shaw.

Hewitt, R. A., \& Pedley, H. M. (1978). The preservation of the shells of Sepia in the middle Miocene of Malta. Proceedings of the GeologistśAssociation, 88(3), 227-237.

Issel, A. (1889). Di una sepia del Pliocene piacentino. Bollettino Malacologico: Società Italiana di Malacologia, 14, 36-58.

Jordá, J. F., Aura, J. E., Martín, C., \& Avezuela, B. (2010). Archaeomalacological remains from the upper Pleistocene-Early Holocene record of the Vestíbulo of Nerja cave (Malaga, Spain). Munibe, 31, 78-87.

Keferstein, W. (1866). Malacozoa Cephalopora. Die Klassen und Ordnungen des Thier-Reichs wissenschaftlich dargestellt in Wort und Bild, 3(2), 519-1500.

Kittl, E. (1886). Über die miozänen Pteropoden von ÖsterreichUngarn mit Berücksichtigung verwandter Vorkommnisse der Nachbarländern. Annalen des Naturhistorischen Hofmuseums, 1, $47-74$.

Košt'ák, M., \& Jagt, J. W. M. (2018). A new species of Sepia (Cephalopoda, Coleoidea) from the Miocene of northwest Germany: A contribution to sepiid palaeobiogeography. Neues Jahrbuch für Geologie und Paläontologie Abhandlungen, 288(3), 273-281.

Košt’ák, M., Ruman, A., Schlögl, J., Hudáčková, N., Fuchs, D., \& Mazuch, M. (2017). Miocene sepiids (Cephalopoda, Coleoidea) from Australia. Fossil Record, 20(2), 159-172.

Košt'ák, M., Schlögl, J., Hudáčková, N., Kroh, A., Halásová, E., Gašparič, R., et al. (2016). Sepia from the Miocene of the Central Paratethys: New taxa and notes on late Cenozoic cuttlefish diversity. Journal of Systematic Palaeontology, 14(12), 1033-1057.

Krijgsman, W., Garcés, M., Langereis, C. G., Daams, R., Van Dam, J., Van der Meulen, A. J., et al. (1996). A new chronology for the middle to late Miocene continental record in Spain. Earth and Planetary Science Letters, 142(3-4), 367-380.

Linnaeus, C. (1758). Systema Naturae per regna tria naturae, secundum classes, ordines, genera, species, cum characteribus, differentiis, synonymis, locis. Editio decima, reformata. Stockholm: Laurentius Salvius.

Lipparini, T. (1934). Fossili del Miocene medio di Fabriano (Marche). Bolletino del R. Ufficio geologico d'Italia, 59(5), 1-11.

Lőrenthey, I. (1899). Sepia im ungarischen Tertiär. Mathematische und Naturwissenschaftliche Berichte aus Ungarn, 15, 20-27.

Mayoral, E., \& Muñiz, F. (1994). A new Sepioid Cephalopoda in the Upper Neogene from the Guadalquivir Basin (Lepe, Huelva, Spain). Coloquios de Paleontología, 46, 161-174.

Mohan, K., \& Chatterji, A. K. (1956). Stratigraphy of the Miocene beds of Kathiawar, western India. Micropaleontology, 2, 349-356
Neige, P. (2003a). Spatial patterns of disparity and diversity of the Recent cuttlefishes (Cephalopoda) across the Old World. Journal of Biogeography, 30(8), 1125-1137.

Neige, P. (2003b). Combining disparity with diversity to study the biogeographic pattern of Sepiidae. Berliner Paläobiologische Abhandlungen, 3, 189-197.

Neige, P. (2006). Morphometrics of hard structures in cuttlefish. Vie et Milieu, 56(2), 121-128.

Neige, P., \& von Boletzky, S. (1997). Morphometrics of the shell of three Sepia species (Mollusca: Cephalopoda): Intra-and interspecific variation. Zoologische Beiträge, 38, 137-156.

Okan, Y., \& Hoşgör, I. (2009). The coleoid cephalopod from the Early Miocene of eastern Mediterranean (Diyarbakır, Turkey). In 62nd Geological Kurultai of Turkey, 13-17 April 2009 (pp. 708-709). Ankara: MTA.

Parona, C. F. (1892). Descrizione die alcuni fossili miocenici di Sardegna. Atti della Società italiana di Scienze naturali e del Museo civico di Storia naturale di Milano, 34, 163-177.

Pasini, G., Garassino, A., Hyžný, M., Baldanza, A., Bizzarri, R., \& Famiani, F. (2014). The bathyal decapod crustacean community from the early Pleistocene of Volterra (Pisa, Tuscany, central Italy). Neues Jahrbuch für Geologie und Paläontologie Abhandlungen, 271(3), 243-259.

Ponzi, G. (1876). I fossili del Monte Vaticano. Atti della Reale Accademia dei Lincei, Serie 2, 3(2), 925-959.

Popov, S. V., Rögl, F., Rozanov, A. Y., Steininger, F. F., Shcherba, I. G., \& Kovac, M. (Eds.). (2004). Lithological-paleogeographic maps of Paratethys. 10 maps, Late Eocene to Pliocene. Courier Forschungsinstitut Senckenberg (Vol. 250, pp. 1-46).

Reid, A., Jereb, P., Roper, C. F. E., \& Jereb, P. (2005). Cuttlefishes. In P. Jereb \& C. F. E. Roper (Eds.), Cephalopods of the world. An annotated and illustrated catalogue of cephalopod species known to date. FAO Species Catalogue for Fishery Purposes (Vol. 4, pp. 56-179). Rome: Food and Agriculture Organization of the United Nations.

Roger, J. (1947). Découverte dune coquille de Sepia (S. cf. vindobonensis Schloenbach) dans le Vindobonien supérieur de Saubrigues (Landes) et histoire paléontologique des Sepiidae. Bulletin de la Societé géologique de France, 5(17), 225-232.

Sacco, F. (1893). I molluschi dei terreni terziarii del Piemonte e della Liguria, 13(b). (Conidae e Conorbidae) (Vol. 2, pp. 55-143). Torino: Clausen.

Sacco, F. (1904). I molluschi dei terreni terziarii del Piemonte e della Liguria, 30. Aggiunte e correzzione. Considerazioni generali. Indice generale del'opera (p. 1-203, i-xxxvi). Torino: Clausen.

Szörényi, E. (1933). Neue tertiäre Sepiinae aus Ungarn nebst Bemerkungen zum zeitlichen Auftreten und zur Entwicklung der Gattung Sepia. Földtani Közlöny, 63, 183-189.

Tiberi, N. (1880). Cefalopodi, pteropodi, eteropodi viventi nel Mediterraneo e fossili nel terreno terziario italiano con aggiunte e correzioni. Bollettino della Società Malacologica Italiana, 6 , $5-49$.

von Schloenbach, U. (1869). Über Sepia vindobonensis Schloenb. sp. nov. aus dem neogenen Mergel von Baden bei Wien. Jahrbuch der Kaiserlich-Königlichen Geologischen Reichsanstalt, 18(3), 289-291.

Wagner, H. (1938). Die dibranchiaten Cephalopoden der mitteloligozänen (Rupélien) Tonschichten von Kiscell und neue Sepiinae aus dem ungarischem Eozän. Annales historico-naturales Musei nationalis hungarici, 31, 179-199. 